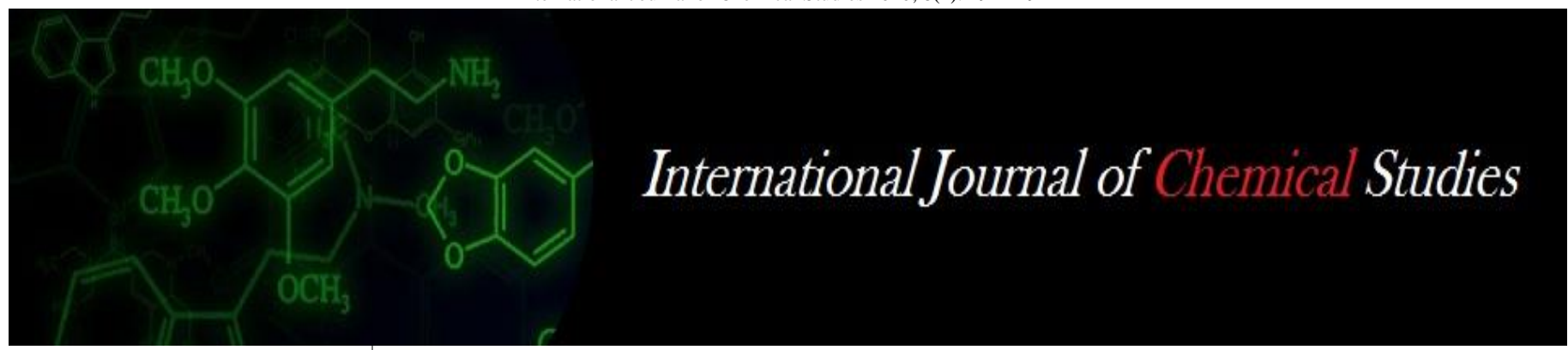

P-ISSN: 2349-8528

E-ISSN: 2321-4902

www.chemijournal.com

IJCS 2020; 8(2): 2911-2914

(C) 2020 IJCS

Received: 01-01-2020

Accepted: 03-02-2020

Dasharath Singh

School of Agriculture, ITM

University, Gwalior, Madhya

Pradesh, India

M Devender Reddy

M.S. Swaminathan School of

Agriculture, Centurion

University of Technology and

Management, Paralakhemundi,

Odisha, India

Girish Pandey

School of Agriculture, ITM

University, Gwalior, Madhya

Pradesh, India

Aunj Kumar

School of Agriculture, ITM

University, Gwalior, Madhya

Pradesh, India

Corresponding Author:

Dasharath Singh

School of Agriculture, ITM

University, Gwalior, Madhya

Pradesh, India

\section{Performance of wheat varieties at different levels of irrigation}

\author{
Dasharath Singh, M Devender Reddy, Girish Pandey and Aunj Kumar
}

DOI: https://doi.org/10.22271/chemi.2020.v8.i2as.9190

\begin{abstract}
An experiment on Performance of wheat varieties to different levels of irrigation was conducted at School of Agriculture, ITM University, Gwalior, M.P. during the winter season of 2015-16. The experiment comprised of three irrigation levels as main treatments and five varieties as sub treatments in split plot design with three replications. The yield improved with irrigation in all the varieties. The increase in frequency of irrigation increased the grain yield. Under no irrigation, variety, Lok-1 gave significantly higher grain yield as compared to other varieties. Under two irrigations, variety GW-366 produced significantly higher grain yield over other varieties - RVW-4106, MP-4010 and Lok-1 and statistically at par with variety MP1203. In treatment where four Irrigations were applied at critical stages (i.e. $20,40,60 \& 80$ DAS) highest grain yield was noted in variety GW-366 which was closely followed by MP-1203 and both these varieties were significantly superior over rest of three varieties at this level of irrigation.
\end{abstract}

Keywords: Grain yield, irrigation, wheat varieties, winter season

\section{Introduction}

Wheat (Triticum aestivum L.) is the most important winter season food crop of India occuping an area of 30.5 million hectare with total production of 101 million tones and a productivity of 3.31 tones ha $^{-1}$ (India Stat, 2018-19). In Madhya Pradesh, it is cultivated in 5.26 million hectare with an annual production of 14.54 million tones and productivity of $2770 \mathrm{~kg} / \mathrm{ha}$ (Madhya Pradesh, Agriculture, Economic Survey- 2014).

Different factors are responsible for higher productivity, these include use of high yielding cultivars, fertilizers and irrigation. One of the major essential parameter for growth and development of plants is irrigation. Water stress is a major constraint for agricultural production in arid and semi arid regions of the world where wheat serves as a principal food crop for human consumption. Water stress reduces wheat grain yield (Kobata et al., 1992) ${ }^{[4]}$. Reduction in grain yield also depends on the genotypes cultivated and physiological stage of the plant at which the plant experiences moisture stress (Moustafa et al. 1996) ${ }^{[6]}$.

Generally, water requirement of semi -dwarf varieties of wheat is about $45 \mathrm{~cm}$ in the form of 4-6 irrigations with a depth of 4-7 cm. Various genotypes of wheat have varying water requirements in different ecosystems of northern part of Madhya Pradesh. There is limited irrigation water to meet the requirement of wheat crop under the changed scenario of the rainfall and its distribution.

Genotypes play a vital role in crop production. The choice of right genotype of wheat helps to augment crop productivity by about 20-25 per cent. Any genotype of wheat before recommended for general cultivation for particular region has to be judged for its potential, tolerance against disease in general and its responsiveness to added water and fertilizer.

Keeping the above points in view, an experiment on performance of wheat varieties to different levels of irrigation was conducted to identify suitable variety and irrigation schedule.

\section{Material and Methods}

An investigation on Performance of wheat varieties to different levels of irrigation was conducted at ITM University, Gwalior (M. P.) during the Rabi season of 2015-16. Three replications consisting three irrigation levels - no irrigation (Control), two irrigations -at CRI and late tillering stages (80-85 DAS) and four irrigations at critical stages (20, 40, 60 and 80 
DAS) were tested in main plots and five varieties MP-1203, RVW-4106, GW-366, MP-4010 and Lok-1 in subplots in split plot design. The experiment site falls under humid subtropical climate and located in between $23^{\circ} 10^{\prime} \mathrm{N}$ latitude and $79^{0} 54^{\prime}$ E longitudes at an elevation of 411.98 meters above mean sea level. The soil type of experimental field was sandy loam in nature with $\mathrm{pH}$ of 7.4 and EC 0.29 dsm-1, having 242 $\mathrm{kg}$ available nitrogen, $20.5 \mathrm{~kg}$ available phosphorus and 456 $\mathrm{kg}$ available potassium.

During the crop growth period, the maximum temperature varied between $18.9^{\circ} \mathrm{C}$ in January third week to $40.1{ }^{\circ} \mathrm{C}$ in April first week and minimum temperature ranged from 3.9 ${ }^{\circ} \mathrm{C}$ in third week of December to $23{ }^{\circ} \mathrm{C}$ in second week of April.

The experimental field was given a pre-sowing irrigation and two ploughings were done by tractor and this was followed by planking each time and after this the field was laid out into plots with appropriate bunds between treatments. The sowing of wheat varieties was done @ $100 \mathrm{~kg} / \mathrm{ha}$ by funnel attached with desi plough, keeping row-to-row distance of $20 \mathrm{~cm}$ on 28 November 2015 and harvested on April 20, 2016. The seeds were covered by planking. The hand weeding was done two months after sowing. After the hand weeding, the field remained free and clean from weeds.

The fertilizers were applied at $60 \mathrm{~kg} \mathrm{~N}, 60 \mathrm{~kg} \mathrm{P} \mathrm{O}_{5}$ and $40 \mathrm{~kg}$ $\mathrm{K}_{2} \mathrm{O} /$ ha. The nitrogen was applied through urea and $\mathrm{P}_{2} \mathrm{O}_{5}$ and $\mathrm{K}_{2} \mathrm{O}$ through urea, DAP and MOP. The full dose of nitrogen, $\mathrm{P}_{2} \mathrm{O}_{5}$ and $\mathrm{K}_{2} \mathrm{O}$ were drilled at $8 \mathrm{~cm}$ deep in the field (at the time of sowing), as a basal dose. Irrigations were given at $5 \pm 1$ $\mathrm{cm}$ as per the treatments besides pre sowing irrigation.

All the agronomic management practices were done uniformly in all the treatments. The observations on plant height, numbers of tiller per meter row length and the yield contributing characters viz., ear head $\mathrm{m}^{-1}$ row length, spike length $(\mathrm{cm})$, number of spike lets spike $^{-1}$, number of grains spike $^{-1}$ and 1000 grains weight $(\mathrm{g})$ and the biological, grain and straw yields were recorded as per standard procedures.

The Harvest Index, the ratio of economic yield to the biological yield was calculated and expressed in per centage as given below

$$
\text { Harvest Index }(\%)=\frac{\text { Economic yield }(\text { grain yield })}{\text { Biological yield }(\text { grain }+ \text { straw })} \times 100
$$

The data obtained on various observations were subjected to statistical analysis by using the techniques of the analysis of variance (ANOVA) and the treatment was tested by F test and Critical difference (CD) at 5\% level of significance (Panse and Sukhatme, 1989) ${ }^{[7]}$ for each character to compare the differences among treatment means.

\section{Results and Discussion Irrigation scheduling}

Scheduling of irrigations significantly affected the various growth parameters of wheat. There was a progressive and significant increase in plant height with increasing number of irrigations from 2 to 4 (Table 1). Plant growth depends on cell division and cell expansion for which adequate water supply is essential (Singh and Singh, 1977) ${ }^{[8]}$. Hence, plants were taller due to increase in irrigation level (Hooda and Agarwal, 1987) ${ }^{[2]}$. Crop receiving four irrigations at critical stages produced more tillers/m row length than the crop which received only two irrigations at CRI stage and late tillering and no irrigation.
Increase in frequency of irrigations increased the number of ear heads/m row length progressively and significantly over no irrigation (Table 2). Significantly more number of grains per ear head and test weight was recorded with crop irrigated four times at critical stages (20, 40, 60 and 80 DAS) over crop irrigated two times at CRI and late tillering stage and no irrigation.

Significant increase in yield attributing characters due to increase in irrigation levels may be due to higher availability of moisture which might have helped in better nutrient absorption by the crop, which in turn resulted in assimilation of photosynthates and better development of yield attributes. Grain yield as well as straw yield increased with increasing irrigation level (Table 3). Crop which received 4 irrigations (at 20, 40,60 \& $80 \mathrm{DAS}$ ) produced 11.67 percent higher grain yield over two irrigations at CRI and late tillering stages (Table 3). Likewise, the crop raised with two irrigation had significant edge over no-post sowing irrigation, which may be due to beneficial effect of soil-moisture regime on growth and yield components (Table 1 and 2). All the growth and yield components increased significantly with the increase in irrigation levels from no irrigation to 2 and 4 . The increase in these yield components alternately resulted in higher grain yield in crop receiving 4 irrigations over 2 irrigations (Table 3). Similar observations were reported by Behera et al. (2002) ${ }^{[1]}$, Kibe and Singh (2003) ${ }^{[3]}$ and Yadav et al. (2005) ${ }^{[9]}$.

The harvest index (Table 3.) increased with increase in levels of irrigation.

\section{Variety}

The growth parameters like plant height, number of tillers/m row length were significantly influenced by varieties (Table 1). At harvest, variety MP-1203 resulted in significantly tallest plant, while Variety GW-366 produced significantly highest number of tiller per plant followed by MP-1203and the tiller number in these two varieties was higher over rest of the genotypes. The differences in growth characters due to genotypes may be attributed to their inherent characteristics. The yield attributing traits like ear heads/m row length, length of ear head, number of grains/ear head and test weight were significantly affected by varieties (Table 2). Genotype GW366 produced significantly higher number of ear heads/row length, longest ear head, heavier ear head and higher number of grains/ear head, 1000 grain weight over other genotypes. Variety GW-366 resulted in significantly higher grain yield over that of MP 4010, RVW 4106 and Lok-1, and was comparable with the yield obtained by the MP 1203 (Table 3). The grain yield recorded with varieties MP4010, RVW 4106 and Lok-1 was comparable.

The higher yield obtained by variety GW 366 was due to its superiority in yield attributes over all other varieties which ultimately resulted in higher grain yield in this variety over other varieties under test.

All the varieties showed more or less similar harvest index. However, maximum and minimum harvest index were noted with variety RVW-4106 and MP 4010 respectively.

\section{Interaction of irrigations $x$ varieties}

Under no irrigation, variety Lok-1 gave significantly higher grain yield as compared to other varieties (Table 4). Under two irrigations, variety, GW-366 produced significantly higher grain yield which was statistically at par with the yield produced by variety MP1203. Under this irrigation level, varieties, RVW-4106, MP-4010 and Lok-1 the grain yield were comparable with each other. 
Four irrigations scheduled at critical stages $(20,40,60 \& 80$ DAS) with variety GW-366 recorded highest grain yield which was closely followed by MP-1203 and both the varieties were significantly superior over rest of three varieties at all three irrigation levels. The GW-366 had higher yield attributes as compared to other varieties. The irrigation further improved these attributes which ultimately resulted in higher grain yield along with four irrigations scheduled at critical stages.

From these results, it can be concluded that growing of wheat varieties G366 and MP 1203 and application of four irrigation at critical stages results in higher grain yield in Gwalior region of Madhya Pradesh.

Table 1: Plant population $\mathrm{m}^{-1}$ row length as influenced by different irrigation schedules and varieties at initial and harvest stage

\begin{tabular}{|c|c|c|c|}
\hline \multirow{2}{*}{ Treatments } & \multicolumn{2}{|c|}{ Plant population $\mathrm{m}^{-1}$ row length } & \multirow[b]{2}{*}{ Plant height at harvest, $\mathrm{cm}$} \\
\hline & Initial stage & Harvest stage & \\
\hline \multicolumn{4}{|l|}{ Irrigation schedule } \\
\hline No irrigation (Control) & 18.08 & 16.95 & 77.60 \\
\hline Two irrigations - at CRI and late tillering stages (80-85 DAS) & 18.45 & 17.09 & 84.29 \\
\hline Irrigation at critical stages $(20,40,60$ and 80 DAS $)$ & 18.42 & 17.17 & 94.47 \\
\hline S. Em \pm & 0.18 & 0.11 & 1.24 \\
\hline $\mathrm{CD}(\mathrm{p}=0.05)$ & NS & NS & 4.86 \\
\hline \multicolumn{4}{|l|}{ Varieties } \\
\hline MP-1203 & 18.46 & 17.20 & 88.50 \\
\hline RVW-4106 & 18.29 & 17.01 & 86.06 \\
\hline GW-366 & 18.24 & 17.00 & 87.40 \\
\hline MP-4010 & 18.46 & 17.10 & 84.70 \\
\hline Lok-1 & 18.15 & 17.03 & 80.60 \\
\hline S. Em \pm & 0.17 & 0.20 & 1.49 \\
\hline $\mathrm{CD}(\mathrm{p}=0.05)$ & NS & NS & 4.35 \\
\hline Interaction (I rrigation X Varities) & NS & NS & \\
\hline
\end{tabular}

Table 2: Yield attributing characters of wheat as influenced by different irrigation schedules and varieties

\begin{tabular}{|c|c|c|c|c|c|}
\hline \multirow[b]{2}{*}{ Treatments } & \multicolumn{5}{|c|}{ Yield attributing characters } \\
\hline & \begin{tabular}{|c|}
$\begin{array}{c}\text { Length of ear } \\
\text { head }(\mathrm{cm})\end{array}$ \\
\end{tabular} & $\begin{array}{c}\text { Number of } \\
\text { grains / ear head }\end{array}$ & $\begin{array}{c}\text { Weight of ear } \\
\text { head }(\mathrm{g})\end{array}$ & $\begin{array}{l}\text { 1000 grain } \\
\text { weight }(g)\end{array}$ & $\begin{array}{c}\text { Number of ear head } \\
\mathbf{m}^{-1} \text { row length }\end{array}$ \\
\hline \multicolumn{6}{|c|}{\begin{tabular}{|l|l|l|l|l|l} 
Irrigation schedule &
\end{tabular}} \\
\hline No irrigation (Control) & 7.15 & 38.59 & 8.14 & 34.88 & 45.61 \\
\hline $\begin{array}{l}\text { Two irrigations - at CRI and late tillering stages (80-85 } \\
\text { DAS) }\end{array}$ & 8.34 & 46.38 & 9.53 & 40.02 & 54.65 \\
\hline Irrigation at critical stages $(20,40,60$ and 80 DAS $)$ & 9.25 & 52.63 & 10.39 & 41.72 & 59.69 \\
\hline S. Em \pm & 0.18 & 0.61 & 0.09 & 0.20 & 1.00 \\
\hline $\mathrm{CD}(\mathrm{p}=0.05)$ & 0.71 & 2.41 & 0.36 & 0.80 & 3.93 \\
\hline \multicolumn{6}{|c|}{ Varieties $(\mathrm{V})$} \\
\hline MP-1203 & 8.21 & 46.93 & 9.52 & 39.27 & 54.20 \\
\hline RVW-4106 & 8.06 & 46.00 & 9.19 & 38.13 & 53.41 \\
\hline GW-366 & 8.79 & 47.77 & 9.89 & 40.33 & 59.29 \\
\hline MP-4010 & 8.35 & 45.42 & 9.26 & 38.64 & 53.50 \\
\hline Lok-1 & 7.81 & 43.21 & 8.90 & 37.99 & 46.19 \\
\hline S. Em \pm & 0.09 & 0.90 & 0.14 & 0.41 & 1.38 \\
\hline $\mathrm{CD}(\mathrm{p}=0.05)$ & 0.27 & 2.61 & 0.41 & 1.20 & 4.03 \\
\hline Interaction (I rrigation X Varities) & NS & NS & NS & NS & NS \\
\hline
\end{tabular}

Table 3: Grain and straw yield and harvest index of wheat as influenced by different irrigation schedules and varieties

\begin{tabular}{|c|c|c|c|}
\hline \multirow{2}{*}{ Treatments } & \multicolumn{2}{|c|}{ Yield $\left(\mathrm{kg} \mathrm{ha}^{-1}\right)$} & \multirow{2}{*}{ Harvest index $(\%)$} \\
\hline & Grain & Straw & \\
\hline \multicolumn{4}{|l|}{ Irrigation schedule } \\
\hline No irrigation (Control) & 2906 & 5034 & 36.64 \\
\hline Two irrigations - at CRI and late tillering stages (80-85 DAS) & 3789 & 5653 & 40.17 \\
\hline Irrigation at critical stages $(20,40,60$ and 80 DAS $)$ & 4231 & 5757 & 42.35 \\
\hline S. Em \pm & 19 & 35 & 0.19 \\
\hline $\mathrm{CD}(\mathrm{p}=0.05)$ & 73 & 38 & 0.74 \\
\hline \multicolumn{4}{|l|}{ Varieties } \\
\hline MP-1203 & 3716 & 5526 & 39.95 \\
\hline RVW-4106 & 3551 & 5196 & 40.47 \\
\hline GW-366 & 3824 & 5707 & 39.88 \\
\hline MP-4010 & 3539 & 5503 & 38.83 \\
\hline Lok-1 & 3580 & 5474 & 39.47 \\
\hline S. Em \pm & 44 & 96 & 0.49 \\
\hline $\mathrm{CD}(\mathrm{p}=0.05)$ & 128 & 281 & NS \\
\hline Interaction (I rrigation X Varities) & $\mathrm{S}^{*}$ & NS & NS \\
\hline
\end{tabular}


Table 4: Interaction effect of Irrigation schedules and varieties on grain yield of wheat $\left(\mathrm{kg} \mathrm{ha}^{-1}\right)$

\begin{tabular}{|c|c|c|c|c|}
\hline \multirow{2}{*}{ Varieties } & \multicolumn{4}{|c|}{ Irrigation levels } \\
\cline { 2 - 5 } & No irrigation & Two irrigations & Four irrigations & Mean \\
\hline MP-1203 & 2843 & 3890 & 4423 & 3716 \\
\hline RVW-4106 & 2910 & 3636 & 4108 & 3551 \\
\hline GW-366 & 2923 & 4007 & 4542 & 3824 \\
\hline MP-4010 & 2707 & 3753 & 4157 & 3539 \\
\hline Lok-1 & 3147 & 3670 & 3924 & 3580 \\
\hline Mean & 2906 & 3789 & 4231 & \\
\hline S. E.m \pm & \multicolumn{5}{|c|}{70} \\
\hline CD (p=0.05) & \multicolumn{5}{|}{} \\
\hline
\end{tabular}

\section{References}

1. Behera UK, Ruwali KN, Verma PK, Pandey HN. Productivity and water-use efficiency of macaroni (Triticum durum) and bread wheat (Triticum aestivum) under varying irrigation levels and schedules in the Vertisols of central Indian. Indian J Agron. 2002; 47(4):518-525.

2. Hooda IS, Agarwal SK. Studies on irrigation, weed control and fertility levels on growth and yield of wheat. Indian J Agron. 1987; 32:261-264.

3. Kibe AM, Subedar Singh. Influence of irrigation, nitrogen adoption zinc on productivity and water use by late sown wheat (Triticum aestivum). Indian J Agron. 2003; 48(3):186-191.

4. Kobata T, Palta JA, Turner NC. Rate of development of posthanthesis water deficits and grain filling of spring wheat. Crop Sci. 1992; 32:128-129.

5. India Stat. statistical tables, 2018-19

6. Moustafa MA, Boersma L, Kronstad WE. Response of four spring wheat cultivars to drought stress. Crop Sci. 1996; 36:982-986.

7. Panse VG, Sukhatme PV. Statistical method for agricultural workers. I.C.A.R., New Delhi, 1967.

8. Singh SK, Singh NP. Monograph 4. Water Technology Centre IARI, New Delhi, 1977.

9. Yadav MS, Bhardwaj AK, Mahendra Singh, Mishra RD. Lal B. Response of late planted wheat to fertility and irrigation levels under shallow water table conditions of mollisols of Uttaranchal and U.P. Farming systems Res. \& Development. 2005; 11(1):60-64. 